\title{
Dynamic Adsorption of Nitric Oxide (NO) in a Fixed-bed Reactor Using Rubber Seed Shell-derived Biochar
}

\author{
Shahreen Izwan Anthonysamy ${ }^{1(\mathbb{D})}$, Pooya Lahijani ${ }^{2 \mathbb{D}}$, Maedeh Mohammadi ${ }^{3(\mathbb{D})}$, Abdul Rahman \\ Mohamed 1,*iD \\ 1 Low Carbon Economy (LCE) Research Group, School of Chemical Engineering, Universiti Sains Malaysia, 14300, \\ Nibong Tebal, Pulau Pinang, Malaysia; areen_vanillaice@yahoo.com (S.I.A.); \\ 2 School of Aerospace Engineering, Universiti Sains Malaysia, 14300, Nibong Tebal, Pulau Pinang, Malaysia; \\ pooya.lahijani@usm.my (P.L.); \\ 3 Faculty of Chemical Engineering, Babol Noshirvani University of Technology, 47148 Babol, Iran; \\ m.mohammadi@nit.ac.ir (M.M.); \\ * Correspondence: chrahman@usm.my (A.R.M.);
}

Scopus Author ID 7402739263

Received: 26.04.2021; Revised: 29.05.2021; Accepted: 1.06.2021; Published: 9.06.2021

\begin{abstract}
Control of nitric oxide emission (NO) as the main constituent of nitrogen oxides $\left(\mathrm{NO}_{\mathrm{x}}\right)$ from combustion sources is a global concern. In this context, this study investigates the adsorption of NO using some biomass-derived adsorbents. Rubber seed shell (RSS) was used as a lignocellulosic residue to develop biochar, modified by metal-doping and alkali activation. The prepared adsorbents, namely, pristine biochar, cerium-loaded biochar and $\mathrm{KOH}$-activated biochar, were used to capture $\mathrm{NO}$ in a dynamic fixed-bed adsorption system. The effect of different initial NO feed concentrations (200 and $350 \mathrm{ppm})$, total gas flow rates $(100,150$ and $200 \mathrm{ml} / \mathrm{min})$, and adsorption temperatures $(30,70$ and 110 ${ }^{\circ} \mathrm{C}$ ) on the adsorption capacity of the adsorbents was investigated. The most suitable operating condition for NO adsorption was found to be the NO feed concentration of $200 \mathrm{ppm}$, inlet gas flow rate of 100 $\mathrm{ml} / \mathrm{min}$ and the adsorption temperature of $30{ }^{\circ} \mathrm{C}$ at which the high $\mathrm{NO}$ adsorption capacity of 81.67 , 142.53 and $470.50 \mathrm{mg} / \mathrm{g}$ was attained for pristine, Ce-loaded, and $\mathrm{KOH}$-activated biochars, respectively. The adsorbents showed high sustainability in the regeneration process within 5 cycles of NO adsorptiondesorption. These results highlight the high potential of RSS-derived biochar for the control of $\mathrm{NO}_{\mathrm{x}}$ emission from flue gases.
\end{abstract}

Keywords: Nitric oxide adsorption; Fixed-bed reactor; Biochar; Metal-doped biochar; alkaliactivated biochar.

(C) 2021 by the authors. This article is an open-access article distributed under the terms and conditions of the Creative Commons Attribution (CC BY) license (https://creativecommons.org/licenses/by/4.0/).

\section{Introduction}

Air pollution is considered one of the major problems around the globe. Day by day, this issue is becoming more serious due to its impact on human health and the environment. One of the main contributors to air pollution is acid deposition, also known as acid rain, which is caused by sulfur oxides $\left(\mathrm{SO}_{\mathrm{x}}\right)$ and nitrogen oxides $\left(\mathrm{NO}_{\mathrm{x}}\right)$ emissions [1]. During the combustion process, $\mathrm{NO}_{\mathrm{x}}$ is formed by the nitrogen bond reaction with oxygen in the air [2]. $\mathrm{NO}_{\mathrm{x}}$ is a pollutant of great concern as it can cause serious respiratory diseases besides being the cause of several environmental issues, including photochemical smog, acid rain and depletion of the ozone layer [3-5]. $\mathrm{NO}_{\mathrm{x}}$ may exist in different forms, among all, nitric oxide is a possible form and comprises almost $90 \%$ of the compounds in $\mathrm{NO}_{\mathrm{x}}$ group [6]. $\mathrm{NO}$ is highly 
reactive because of being a diatomic radical with one unpaired electron and because of being toxic, its removal from flue gases is crucial [7].

The current most practical technique for reducing $\mathrm{NO}_{\mathrm{x}}$ emissions is a selective catalytic reduction with ammonia ( $\mathrm{NH}_{3}-\mathrm{SCR}$ ) which is carried out at temperatures of $300-400{ }^{\circ} \mathrm{C}$ [8]. Yet, the traditional SCR may not be applicable for the removal of $\mathrm{NO}_{\mathrm{x}}$ in the industries such as steel, glass, cement and so on, whose flue gas temperature is low (100 to $\left.200{ }^{\circ} \mathrm{C}\right)$ and heating up the gas would be a burdensome operating cost [9]. Alternatively, $\mathrm{NO}$ oxidation to $\mathrm{NO}_{2}$ and its adsorption can be utilized for $\mathrm{NO}_{\mathrm{x}}$ emission abatement. It is worth noting that the adsorption extent of $\mathrm{NO}_{2}$ is much higher than $\mathrm{NO}$; this is because $\mathrm{NO}$ is a supercritical fluid at ambient temperature and its physical adsorption on the adsorbent is low [10].

Some researchers have reported catalytic oxidation of $\mathrm{NO}$ to $\mathrm{NO}_{2}$ over carbonaceous materials. Some recent studies have reported the use of pristine or modified activated carbon [3, 11-13], sewage sludge-derived char [12] and metal oxide-loaded activated carbon [14] for the oxidation of NO. In continuing efforts to develop cost-effective and sustainable materials for NO uptake and adsorption, considerable attention has been paid to biochar, which is the solid product obtained from the thermochemical conversion of biomass, including pyrolysis gasification hydrothermal carbonization as well as flash carbonization $[15,16]$. Recently, some studies [17] have reported the use of metal-loaded biochar for SCR of NO with ammonia at low temperature, however, the catalytic oxidation of NO over biochar has been scarcely reported [18]. Biochar has abundant oxygen-containing functional groups [19], which can significantly contribute to the oxidation of $\mathrm{NO}$ to $\mathrm{NO}_{2}$ that its physical adsorption on the adsorbent is considerably higher than NO [20].

The selection of biomass for the development of biochar mainly depends on the abundance and availability of the lignocellulosic wastes [21]. In Malaysia, which is among the top producers of natural rubber globally, rubber seed shell (RSS) is plentifully available as a lignocellulosic waste [22]. It is produced after extracting oil from the rubber seed kernel, which itself is a by-product of the rubber tree beside latex which is the main product. Hence, the use of RSS as a locally available lignocellulosic waste to produce biochar for NO oxidation would be a viable solution both to reduce the solid waste and, also, to control the $\mathrm{NO}_{\mathrm{x}}$ emission from combustion sources.

Generally, biochar's porosity properties and surface chemistry can be improved through some physical and/or chemical modifications [16]. In this context, in this study, pristine biochar was modified through two approaches: metal-doping and alkali-activation and used as adsorbent for NO uptake. In this regard, cerium oxide was loaded on the pristine biochar through impregnation followed by calcination; this was to obtain Ce-loaded biochar. As the second adsorbent, pristine biochar was activated using potassium hydroxide solution to obtain $\mathrm{KOH}$-activated biochar. Both adsorbents and the pristine biochar were used to uptake NO in a dynamic fixed-bed system. The influence of various operating parameters such as NO feed concentration, total gas flowrate and adsorption temperature on the adsorption capacity of the adsorbents was studied and the results were discussed.

\section{Materials and Methods}

\subsection{Biomass feedstock.}

Rubber seed shell (RSS), as the lignocellulosic feedstock, was used to prepare biochar. The shells were washed, dried, and crushed using a mechanical crusher to a particle size of 
around $63 \mu \mathrm{m}$. Proximate analysis showed that the RSS contained $78 \%$ moisture, $0.4 \%$ ash and $22 \%$ fixed carbon on dry basis. Ultimate analysis indicated that the percentage of $\mathrm{C}, \mathrm{O}, \mathrm{H}, \mathrm{S}$ and $\mathrm{N}$ in the RSS biomass was $48.36,45.45,5.75,0.30$ and $0.14 \%$, respectively.

\subsection{Preparation of RSS-based adsorbents.}

Three RSS-based adsorbents, including raw biochar, Ce-loaded biochar and $\mathrm{KOH}-$ activated biochar, were synthesized and used for NO uptake in this study. Raw biochar was produced in a carbonization unit by pyrolyzing the RSS biomass at $700{ }^{\circ} \mathrm{C}$ temperatures for 90 min. Metal-doped biochar was prepared by impregnating the RSS biochar with cerium nitrate solution $\left(\mathrm{Ce}\left(\mathrm{NO}_{3}\right)_{3} \cdot 6 \mathrm{H}_{2} \mathrm{O}\right)$ and then calcining the sample under $\mathrm{N}_{2}$ at $500{ }^{\circ} \mathrm{C}$ to obtain $\mathrm{CeO}_{2}-$ loaded biochar following the method described in our previous study [18]. To prepare the $\mathrm{KOH}$-activated biochar, the RSS biochar was impregnated with potassium hydroxide $(\mathrm{KOH})$ at a mass ratio of 2:1 (alkali chemical: biochar). The chemically activated biochar was then heated under $\mathrm{N}_{2}$ at $700{ }^{\circ} \mathrm{C}$ for $3 \mathrm{~h}$. After cooling, the sample was washed with $\mathrm{HCl}$ and distilled water until a neutral $\mathrm{pH}$ was reached. Finally, the sample was oven-dried at $105^{\circ} \mathrm{C}$ and stored in an air-tight container for adsorption experiments.

\subsection{NO adsorption studies.}

NO adsorption tests were performed in a continuous fixed-bed reactor system. The system consisted of three major components: fixed-bed reactor, mass flow controllers and flue gas analyzer system. The fixed bed reactor for $\mathrm{NO}$ adsorption consisted of a stainless steel tube (Swagelok, $1.25 \mathrm{~cm}$ OD, $1.0 \mathrm{~cm}$ ID, $50 \mathrm{~cm}$ length), located inside a vertical tube furnace (MiniMite Tube Furnace, Lindberg/Blue, Model TF55030A). A K-type thermocouple (Patos, DE305) was placed in the middle of the adsorber to monitor the adsorption temperature.

Two mass flow controllers (Aalborg) were installed to regulate the flow rate of $\mathrm{O}_{2}$ and $\mathrm{NO}$ in $\mathrm{N}_{2}$ gas mixture. The outlet concentration of $\mathrm{NO}$ before and after the adsorption experiment was measured using a gas analyzer system (IMR Combustion-Gas Analyzer System 5000/400 with integrated). The gas analyzer was used to measure the concentration of NO gas in ppm.

For testing the NO adsorption activity of either pristine or cerium and $\mathrm{KOH}$ impregnated RSS biochar samples, $1 \mathrm{~g}$ of the prepared adsorbent was placed at the center of the fixed-bed adsorber and borosilicate glass wool was used as the support. Then, a flow of nitrogen gas was allowed to pass through the reactor column at $140{ }^{\circ} \mathrm{C}$ for $15 \mathrm{~min}$ to remove moisture or any unwanted foreign compounds from the biochar samples. After that, a flow of gas mixture, consisting of $\mathrm{NO}(200$ or $350 \mathrm{ppm})$ and $\mathrm{O}_{2}(15 \%)$, was passed through the biochar bed. The inlet and outlet concentrations of NO were measured using a gas analyzer. The NO concentration was recorded continuously at an interval of 1 min until the breakthrough point was accomplished. The effect of NO feed concentration (200 or $350 \mathrm{ppm}$ ), total gas flow rate $(100,150$ and $200 \mathrm{ml} / \mathrm{min})$ and adsorption temperature $\left(30,70\right.$ and $\left.110{ }^{\circ} \mathrm{C}\right)$ on the NO uptake capacity of the adsorbent was studied. The NO uptake capacity was calculated from the integration of the breakthrough curve as shown in Equation (1) [23]:

$$
Q_{S}=\frac{F \times \int_{0}^{t}\left(C_{0}-C\right) d t}{m}
$$


where $Q_{S}$ represents the NO adsorption capacity of the adsorbent $(\mathrm{mg} / \mathrm{g}), F$ is the inlet feed flow rate $\left(\mathrm{m}^{3} / \mathrm{min}\right), m$ is the amount of adsorbent $(\mathrm{g}), C_{0}$ and $C$ stands for the inlet and outlet concentration of $\mathrm{NO}\left(\mathrm{mg} / \mathrm{m}^{3}\right)$, respectively and $t$ is the adsorption time ( $\left.\mathrm{min}\right)$. Each experimental run for NO adsorption was repeated three times to increase the accuracy of the results and the average values were reported.

\section{Results and Discussion}

In this study, to improve the pristine biochar's physicochemical attributes and hence enhance its NO uptake capacity, two modifications were carried out on the raw biochar. In the first method, Ce-loaded biochar was developed through impregnation followed by calcination. The introduction of ceria $\left(\mathrm{CeO}_{\mathrm{x}}\right)$ on the biochar was because of the exceptional oxygen storage capacity of ceria which could enhance the oxidation of $\mathrm{NO}$ to $\mathrm{NO}_{2}[18,24]$. As the second approach to developing an adsorbent with high uptake capacity, $\mathrm{KOH}$-activated biochar was developed. This was because alkaline activation of biochar could considerably improve the surface area and porosity of the biochar and, also increase the oxygen content and surface basicity [25]. The surface basicity of biochar was beneficial for the adsorption of NO gas with acidic character. In the next step, the developed adsorbents, including pristine biochar, Celoaded biochar and $\mathrm{KOH}$-activated biochar, were tested in a dynamic adsorption system for NO adsorption and the results are presented and discussed here.

\subsection{Effect of NO feed concentration.}

Figure 1 shows the breakthrough curves for the NO uptake capacity at different NO feed concentrations by pristine, $\mathrm{Ce}$-loaded and $\mathrm{KOH}$-activated biochars. The total gas flow rate and adsorption temperature remained constant at $100 \mathrm{ml} / \mathrm{min}$ and $30{ }^{\circ} \mathrm{C}$ during the $\mathrm{NO}$ adsorption test. Table 1 also shows the NO uptake capacity by various biochar samples at different NO feed concentrations.

Table 1. NO uptake capacity by various adsorbents at different NO feed concentrations.

\begin{tabular}{l|c|c|c} 
Adsorbent & $\begin{array}{c}\text { NO feed concentration } \\
\mathbf{p p m})\end{array}$ & $\begin{array}{c}\text { Breakthrough time } \\
(\mathbf{m i n})\end{array}$ & $\begin{array}{c}\text { NO adsorption capacity } \\
(\mathbf{m g} / \mathbf{g})\end{array}$ \\
\hline Pristine biochar & 200 & 8 & 81.67 \\
\hline & 350 & 6 & 100.00 \\
\hline Ce-loaded biochar & 200 & 18 & 142.53 \\
\hline & 350 & 14 & 144.36 \\
\hline KOH- activated biochar & 200 & 23 & 470.59 \\
\hline & 350 & 17 & 674.36
\end{tabular}

Considering all the investigated adsorbents, it can be observed that lower initial NO concentration $(200 \mathrm{ppm})$ resulted in a longer breakthrough time $\left(\mathrm{t}_{\mathrm{b}}\right)$. The breakthrough time corresponding to the time at which $\mathrm{C} / \mathrm{C}_{0}=0.05$ reduced in all cases when the feed concentration of NO increased. Besides, the saturation time $\left(\mathrm{t}_{\mathrm{s}}\right)$, which refers to the time needed for the adsorbent bed to reach the equilibrium $\left(\mathrm{C} / \mathrm{C}_{0}=0.95\right)$, tended to become longer when a lower initial NO concentration (200 ppm) was used. At this condition, a lower amount of NO molecules entered the reactor and hence it took a long time to reach the saturation point [26, 27]. In contrast, at $350 \mathrm{ppm}$, the adsorbent bed tended to saturate faster, and a shorter saturation time was observed. This was because, at higher NO concentration, a larger driving force resulted from the concentration gradient between the bulk and the surface of the adsorbent, 
which enhanced the mass transfer, diffusion, and adsorption of No on the adsorbent active sites [28].
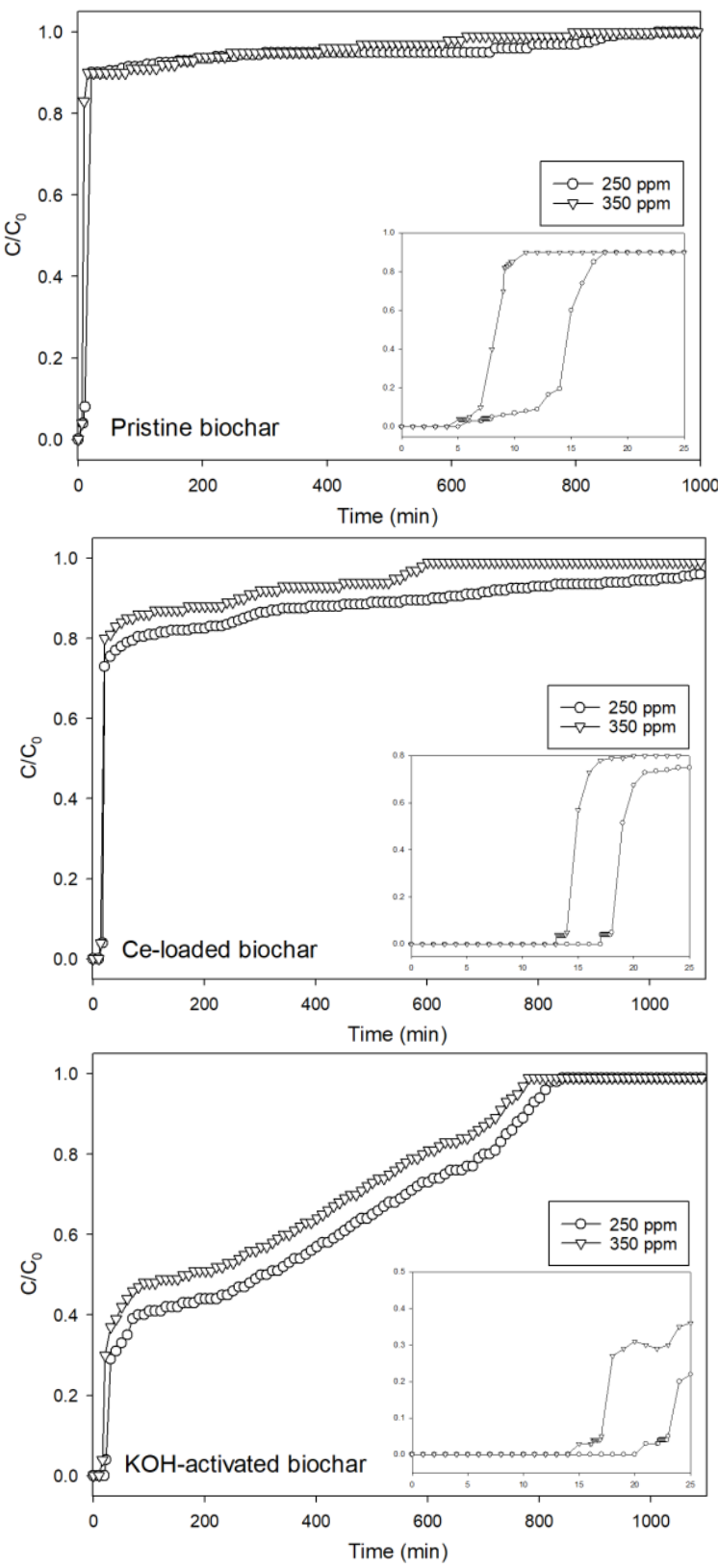

Figure 1. Breakthrough curve for NO adsorption on the prepared adsorbents at different $\mathrm{NO}$ feed concentrations (total gas flow rate: $100 \mathrm{ml} / \mathrm{min}$ and adsorption temperature: $30{ }^{\circ} \mathrm{C}$ ). The inset shows the variation in $\mathrm{C} / \mathrm{C}_{0}$ in the first minutes of adsorption.

In terms of the adsorption capacity, it was found that the adsorption capacity increased directly with an increase in the initial NO feed concentration. Based on the results presented in Table 1, it was identified that with an increase in the initial NO feed concentration from 200 to $350 \mathrm{ppm}$, the NO adsorption capacity also enhanced from 81.67 to $100.0 \mathrm{mg} / \mathrm{g}$ for pristine, from 142.53 to $144.36 \mathrm{mg} / \mathrm{g}$ for Ce-loaded biochar and from 470.59 to $674.36 \mathrm{mg} / \mathrm{g}$ for $\mathrm{KOH}$ activated biochar. At the same time, it was observed that as the initial NO feed concentration increased from 200 to $350 \mathrm{ppm}$, the breakthrough time decreased from 8 to $6 \mathrm{~min}$ for pristine, from 18 to $14 \mathrm{~min}$ for Ce-loaded biochar and from 23 to $17 \mathrm{~min}$ for $\mathrm{KOH}$-activated biochar. When the initial NO feed concentration increased, more adsorption sites were utilized, hence the breakthrough time was shortened. At higher concentration gradients, the diffusion and mass transfer rate increased, therefore, the gas molecules transported quickly into the adsorbent 
pores. Besides, the enhancement in the adsorption capacity at higher concentrations was because of the higher driving force, which could overcome the mass transfer resistance [29].

\subsection{Effect of total gas flow rate.}

To identify the effect of different initial gas flowrates on NO adsorption capacity, gas flowrates of 100, 150 and $200 \mathrm{ml} / \mathrm{min}$ were studied. While the initial NO feed concentration and the adsorption temperature were held constant at $200 \mathrm{ppm}$ and $30{ }^{\circ} \mathrm{C}$. Figure 2 and Table 2 display the breakthrough curves and NO adsorption capacity results for all the tested adsorbents.

As can be seen in Table 2, the adsorption capacity of all adsorbents was found to decrease with an increase in the flow rate from 100 to $200 \mathrm{ml} / \mathrm{min}$. Each of the adsorbents showed the highest adsorption capacity at $100 \mathrm{ml} / \mathrm{min}$ with $81.67,142.53$ and $470.59 \mathrm{mg} / \mathrm{g}$ for pristine, Ce-loaded and $\mathrm{KOH}$-activated biochar, respectively. According to Figure 3, the breakthrough curve was slightly steeper as the initial total gas flow rate increased for all adsorbents, which was associated with an increased mass transfer rate [30]. From Table 2, it can be observed that the breakthrough time increased with respect to the gas flowrate in the order of $200<150<100 \mathrm{ml} / \mathrm{min}$ for all the tested adsorbents. It was identified that the breakthrough time at $100 \mathrm{ml} / \mathrm{min}$ for all adsorbents was significantly longer compared to those at 150 and $200 \mathrm{ml} / \mathrm{min}$. Residence time is an essential factor in the NO adsorption [31]. High adsorption capacity can be obtained at a lower initial total gas flow rate. This is due to the fact that at lower gas flow rates, the residence time is longer, and the gas molecules have more chance to be transported from the gas bulk to the adsorbent surface. At this condition, the gas molecules have more time to diffuse into adsorbent pores, whereby in return, high adsorption capacity could be achieved $[32,33]$.

On the contrary, it was observed that the breakthrough time occurred earlier at a higher gas flow rate. This is due to the decrement in residence time and thus the contact time between the adsorbate and the adsorbent surface sites. At a higher gas flow rate, the mass transfer in the gas film is enhanced, but at the same time, the thickness of the mass transfer boundary around the adsorbent is reduced, causing a decrease in the adsorption capacity [34]. Therefore, by increasing the initial total gas flow rate, although the mass transfer resistance in the gas phase decreases, but shorter residence time results in lower adsorption capacity. Yet, quick saturation of the adsorption column, which is highly associated with the high mass transfer rate, results in shorter breakthrough and saturation times [35]. Based on the results of this study, it can be concluded that a lower initial total gas flowrate was preferable for all the tested adsorbents to achieve higher NO adsorption and a longer breakthrough time.

Table 2. NO adsorption uptake by various adsorbents at different total gas flow rates.

\begin{tabular}{l|c|c|c} 
Adsorbent & $\begin{array}{c}\text { Total gas flow rate } \\
(\mathbf{m l} / \mathbf{m i n})\end{array}$ & $\begin{array}{c}\text { Breakthrough time } \\
(\mathbf{m i n})\end{array}$ & $\begin{array}{c}\text { NO adsorption capacity } \\
(\mathbf{m g} / \mathbf{g})\end{array}$ \\
\hline Pristine biochar & 100 & 8 & 81.67 \\
\hline & 150 & 7 & 59.97 \\
\hline & 200 & 6 & 21.83 \\
\hline Ce-loaded biochar & 100 & 18 & 142.53 \\
\hline & 150 & 15 & 94.43 \\
\hline $\begin{array}{l}\text { KOH-activated } \\
\text { biochar }\end{array}$ & 200 & 12 & 42.54 \\
\hline & 100 & 23 & 470.59 \\
\hline & 150 & 21 & 267.30 \\
\hline & 200 & 18 & 217.94
\end{tabular}



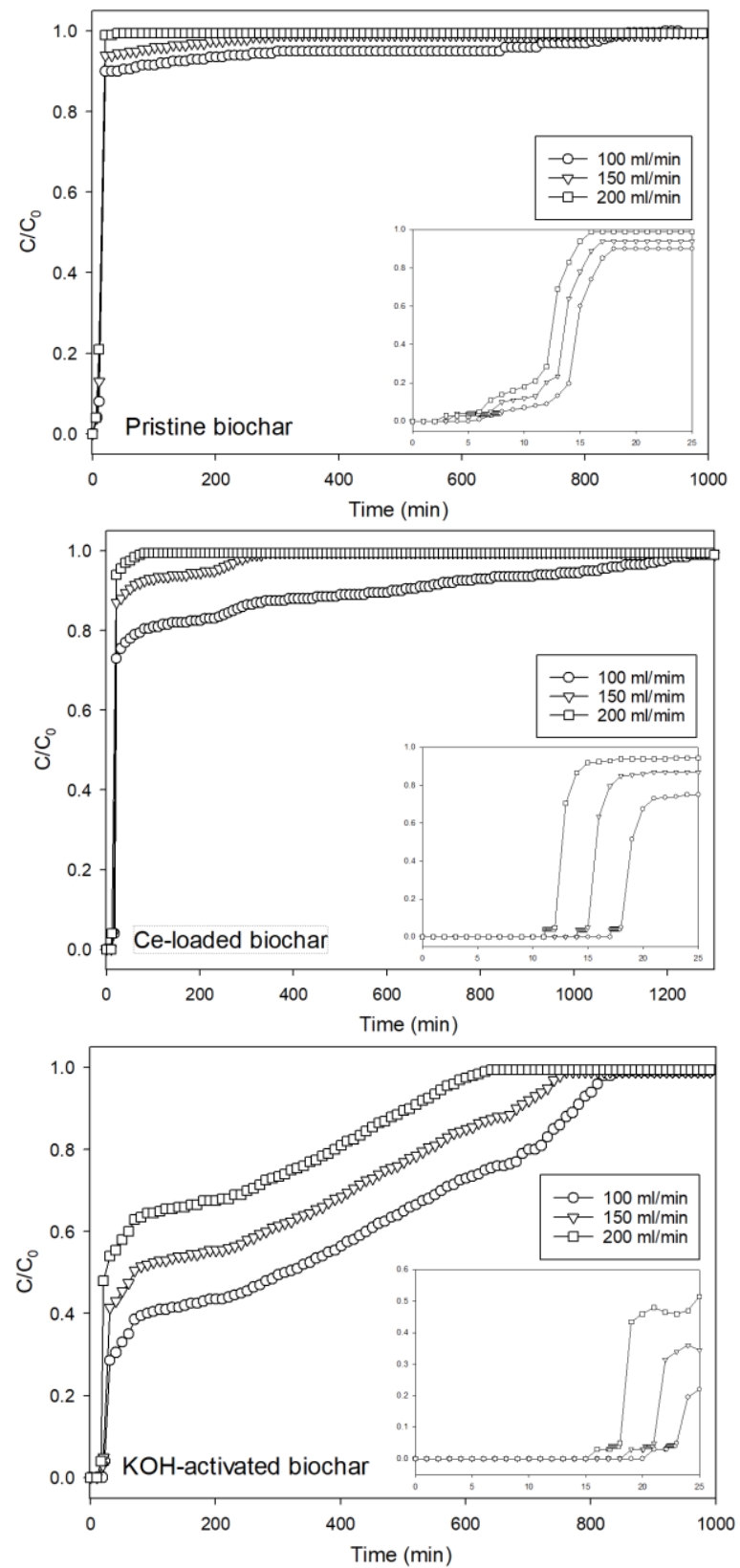

Figure 2. Breakthrough curve for NO adsorption on the prepared adsorbents at different total gas flow rates (NO feed concentration: $200 \mathrm{ppm}$ and adsorption temperature: $30^{\circ} \mathrm{C}$ ). The inset shows the variation in $\mathrm{C} / \mathrm{C}_{0}$ in the first minutes of adsorption.

\subsection{Effect of adsorption temperature.}

Adsorption temperature is another important factor in determining the adsorbent's performance and suitability in post-combustion capture. To investigate the effect of adsorption temperature on $\mathrm{NO}$ adsorption, different temperatures of 30,70 and $110{ }^{\circ} \mathrm{C}$ were applied for $\mathrm{NO}$ adsorption on the adsorbents. In this experiment set, the NO feed concentration and the initial total gas flowrate were held constant at $200 \mathrm{ppm}$ and $100 \mathrm{ml} / \mathrm{min}$, respectively. Figure 3 and Table 3 show the NO adsorption performance of the adsorbents in terms of breakthrough time and adsorption capacity.

Based on the breakthrough results, it can be identified that all the tested adsorbents showed a similar trend whereby the breakthrough time and NO adsorption capacity decreased with an increase in the adsorption temperature from 30 to $110^{\circ} \mathrm{C}$. It was observed that the highest adsorption capacities were obtained at $30{ }^{\circ} \mathrm{C}$, which were $81.67 \mathrm{mg} / \mathrm{g}$ for pristine, $142.53 \mathrm{mg} / \mathrm{g}$ for $3 \%$ Ce-loaded and $470.59 \mathrm{mg} / \mathrm{g}$ for $\mathrm{KOH}$-activated biochar. This finding 
signifies that preferable NO adsorption takes place at lower adsorption temperature. Similar results were observed in the following reported literature. Zhao et al. [23], developed a functionalized molecular imprinted adsorbents (MIP) for NO adsorption. Based on the study, the highest $\mathrm{NO}$ adsorption was $12.1 \mathrm{mg} / \mathrm{g}$, which was obtained at a low adsorption temperature $\left(40{ }^{\circ} \mathrm{C}\right)$. In another study by Al-Rahbi and Williams [36], who investigated the NO adsorption on waste tire activated carbon, it was reported that the highest NO removal was achieved at low adsorption temperature $\left(25^{\circ} \mathrm{C}\right)$.

In contrast, at higher adsorption temperature, lower $\mathrm{NO}$ adsorption capacity and shorter breakthrough time were observed, suggesting that the adsorption process was exothermic in nature. Most adsorbent active sites were filled and occupied by the gas molecules at high adsorption temperatures. Hence, the diffusion resistance increased, causing the adsorption capacity to be decreased. At elevated temperatures, the adsorption equilibrium is reached faster and the saturation point is achieved in a shorter period of time due to the accelerated diffusion of gas molecules to the pores of the adsorbent at high temperatures [37].

Goel et al. [38] suggest that when the adsorption temperature increases, the surface energy and gas diffusion rate increase, causing the gas molecules' stability on the adsorbent surface to decrease. This situation will lead to desorption and consequently decreases the adsorption capacity. Ammendola et al. [39], also discussed that higher adsorption temperature leads to a rapid gas adsorption process, resulting in rapid saturation of the adsorbent bed, thus decreasing the breakthrough time.

Table 3. NO adsorption uptake by various adsorbents at different adsorption temperatures.

\begin{tabular}{l|c|c|c} 
Adsorbent & $\begin{array}{c}\text { Adsorption } \\
\text { temperature } \\
\mathbf{(} \mathbf{C})\end{array}$ & $\begin{array}{c}\text { Breakthrough } \\
\text { time } \\
(\mathbf{m i n})\end{array}$ & $\begin{array}{c}\text { NO adsorption } \\
\text { capacity } \\
(\mathbf{m g} / \mathbf{g})\end{array}$ \\
\hline Pristine biochar & 30 & 8 & 81.67 \\
\hline & 70 & 6 & 64.14 \\
\hline & 110 & 5 & 34.07 \\
\hline Ce-loaded biochar & 30 & 18 & 142.53 \\
\hline & 70 & 16 & 129.70 \\
\hline KOH-activated biochar & 30 & 11 & 95.42 \\
\hline & 70 & 23 & 470.59 \\
\hline & 110 & 19 & 385.32 \\
\hline
\end{tabular}

\subsection{Regeneration study in fixed-bed adsorption reactor.}

For industrial-scale applications, the renewability of the adsorbent and its stability are significantly important. Therefore, the ability to have a good regeneration cycle and also high adsorption capacity are highly preferred. To assess the renewability of the adsorbents, after each adsorption process at $30{ }^{\circ} \mathrm{C}$, the adsorbent was heated under $\mathrm{N}_{2}$ to $140{ }^{\circ} \mathrm{C}$ to desorb the captured gas and this cycle was repeated 5 times; the results are shown in Figure 4 . The regeneration study on the Ce-loaded and $\mathrm{KOH}$-activated biochar was carried out at $200 \mathrm{ppm}$ initial NO concentration of $200 \mathrm{ppm}$, a total gas flow rate of $100 \mathrm{ml} / \mathrm{min}$ and adsorption temperature of $30^{\circ} \mathrm{C}$. 

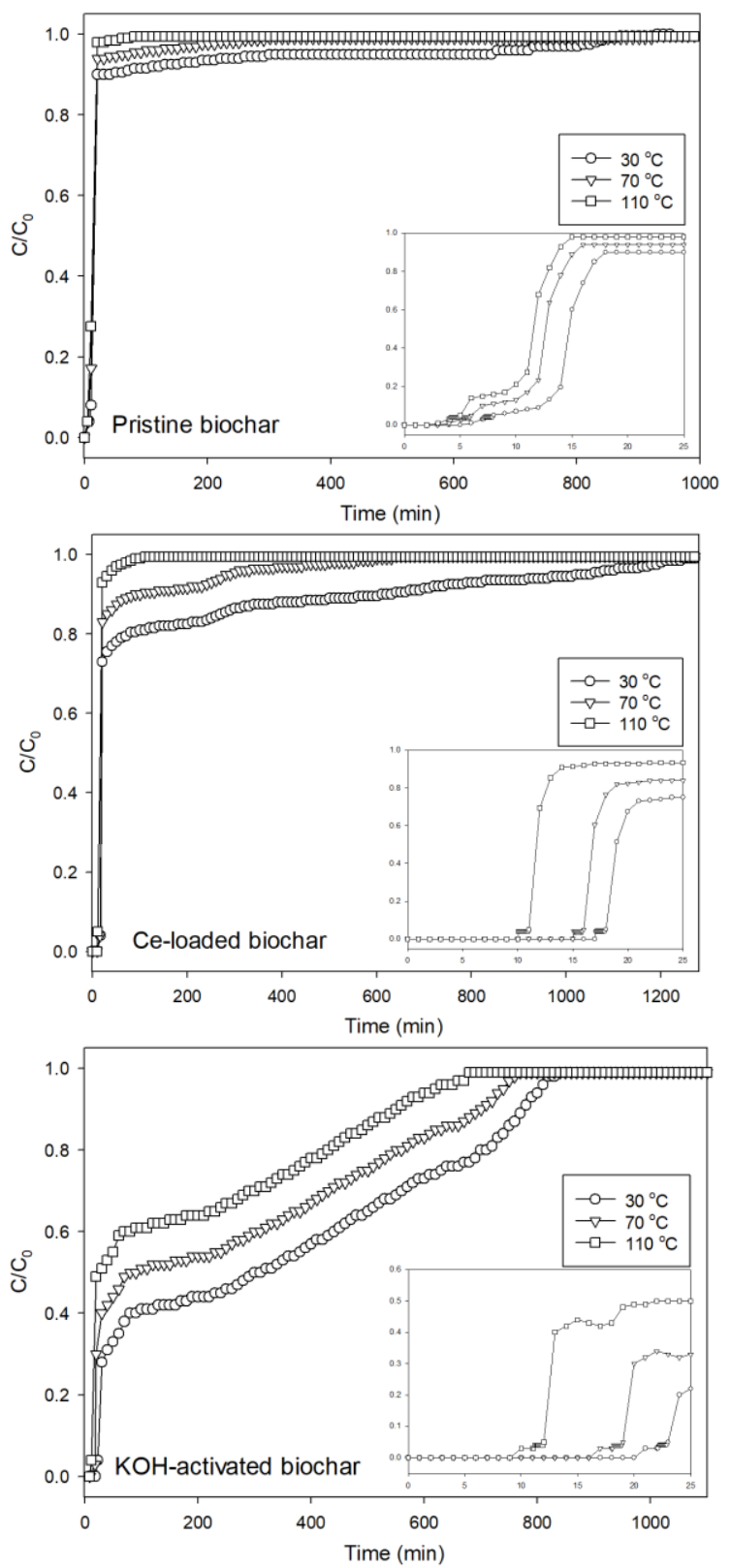

Figure 3. Breakthrough curve for $\mathrm{NO}$ adsorption on the adsorbents at different adsorption temperatures (NO feed concentration: $200 \mathrm{ppm}$ and total gas flow rate: $100 \mathrm{ml} / \mathrm{min}$ ). The inset shows the variation in $\mathrm{C} / \mathrm{C}_{0}$ in the first minutes of adsorption

Based on the results presented in Figure 4, it can be observed that the regeneration performance shown by both cerium and alkali-loaded biochars was stable with an only a slight decrease in the adsorption capacity. This suggests that both adsorbents can be used repeatedly. The adsorption capacity of the alkali-loaded biochar decreased by less than $20 \%$ after 5 regeneration cycles. In comparison, Ce-loaded biochar displayed good regeneration performance. Only a slight decrease of $10 \%$ was observed in the adsorption capacity after 5 cycles. It was also observed that after several cycles, the amount of adsorbed NO slightly decreased, which is probably due to the incomplete removal of the gas molecules during the desorption process and blockage of pores by some remaining gas molecules that were not efficiently released during the desorption process [37]. Overall, both the cerium and alkaliloaded biochars could be easily regenerated due to the weak interactions between the adsorbents' active sites and NO, specifying physisorption or a weak chemisorption process [40]. This easy regeneration and sustainable adsorption capacity can be regarded as two significant advantages of the developed adsorbents for NO adsorption from flue gas. 


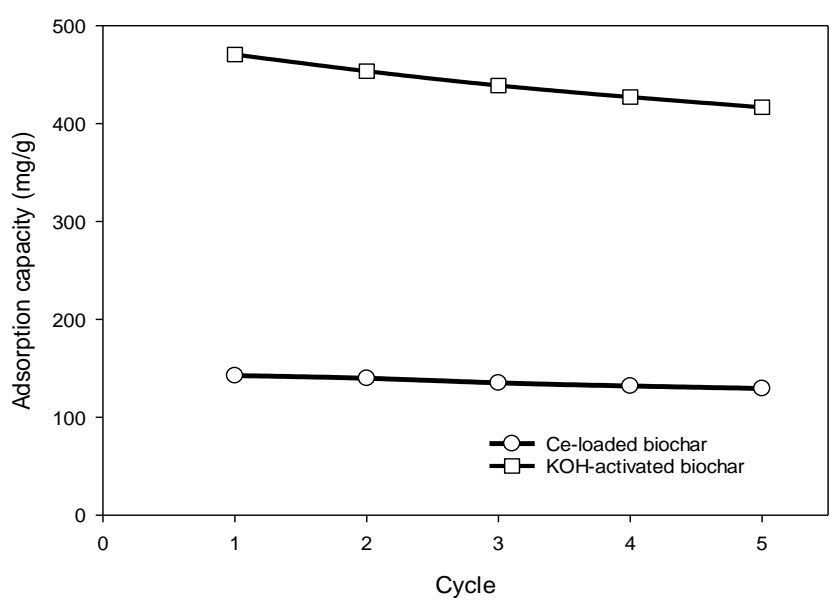

Figure 4. Regeneration performance of Ce-loaded and $\mathrm{KOH}$-activated biochar adsorbents at optimized conditions: $200 \mathrm{ppm}$ NO feed concentration, $100 \mathrm{ml} / \mathrm{min}$ total gas flowrate and $30{ }^{\circ} \mathrm{C}$ adsorption temperature

Comparing the $\mathrm{NO}$ uptake capacity of the Ce-loaded and $\mathrm{KOH}$-activated biochars with those available in the literature (Table 4) signifies the high potential of these adsorbents to remove NO from the combustion sources.

Table 4. Comparison of the NO uptake capacity of different carbon-based adsorbents from the literature in fixed-bed adsorption system.

\begin{tabular}{|c|c|c|c|c|}
\hline Adsorbent & $\begin{array}{l}\text { NO concentration in the } \\
\text { gas }\end{array}$ & $\begin{array}{l}\text { Adsorption } \\
\text { condition }\end{array}$ & $\begin{array}{l}\text { NO uptake } \\
\text { capacity }\end{array}$ & References \\
\hline $\begin{array}{l}\text { Ordered mesoporous } \\
\text { carbon (OMC) and } \\
\text { cerium-loaded OMC }\end{array}$ & $500 \mathrm{ppm}$ & $\begin{array}{l}\text { P: atmospheric } \\
\mathrm{T}: 50^{\circ} \mathrm{C}\end{array}$ & $\begin{array}{c}19.4 \mathrm{mg} / \mathrm{g} \\
(\mathrm{OMC}) \\
22.0 \mathrm{mg} / \mathrm{g}(\mathrm{Ce}- \\
\text { OMC })\end{array}$ & [41] \\
\hline $\begin{array}{l}\text { Coconut shell-based } \\
\text { activated carbon }\end{array}$ & $500 \mathrm{ppm}$ & $\begin{array}{l}\text { P: atmospheric } \\
\text { T: } 25^{\circ} \mathrm{C}\end{array}$ & $23.0 \mathrm{mg} / \mathrm{g}$ & [42] \\
\hline $\begin{array}{l}\text { Cerium loaded palm } \\
\text { shell activated carbon } \\
(\mathrm{Ce} / \mathrm{PSAC})\end{array}$ & $500 \mathrm{ppm}$ & $\begin{array}{l}\mathrm{P}: \text { atmospheric } \\
\mathrm{T}: 150^{\circ} \mathrm{C}\end{array}$ & $3.5 \mathrm{mg} / \mathrm{g}$ & [43] \\
\hline $\begin{array}{l}\text { Molecularly } \\
\text { imprinted adsorbents }\end{array}$ & $1500 \mathrm{ppm}$ & $\begin{array}{l}\text { P: atmospheric } \\
\mathrm{T}: 40^{\circ} \mathrm{C}\end{array}$ & $12.1 \mathrm{mg} / \mathrm{g}$ & {$[26]$} \\
\hline Ce-loaded biochar & $2000 \mathrm{ppm}$ & $\begin{array}{l}\text { P: atmospheric } \\
\text { T: } 30^{\circ} \mathrm{C}\end{array}$ & $142.53 \mathrm{mg} / \mathrm{g}$ & This study \\
\hline $\begin{array}{l}\text { KOH-activated } \\
\text { biochar }\end{array}$ & $2000 \mathrm{ppm}$ & $\begin{array}{l}\text { P: atmospheric } \\
\mathrm{T}: 30^{\circ} \mathrm{C}\end{array}$ & $470.59 \mathrm{mg} / \mathrm{g}$ & This study \\
\hline
\end{tabular}

\section{Conclusions}

Three RSS-derived adsorbents, including pristine, Ce-loaded biochar and $\mathrm{KOH}-$ activated biochars, were used to study the dynamic NO adsorption in a fixed-bed reactor. The effects of operating variables including different initial NO feed concentration (200 ppm and $350 \mathrm{ppm})$, total gas flow rate $(100,150$ and $200 \mathrm{ml} / \mathrm{min})$, and adsorption temperatures $(30,70$, and $110{ }^{\circ} \mathrm{C}$ ) on the NO breakthrough curves and the adsorption capacity were investigated. Results show that with an increase in the initial NO feed concentration from 200 to $350 \mathrm{ppm}$, the NO adsorption capacity increased from 81.67 to $100.00 \mathrm{mg} / \mathrm{g}$ for pristine, 142.53 to 144.36 $\mathrm{mg} / \mathrm{g}$ for Ce-loaded and 470.59 to $674.36 \mathrm{mg} / \mathrm{g}$ for $\mathrm{KOH}$-activated biochar. An increase in the total gas flow rate from 100 to $200 \mathrm{ml} / \mathrm{min}$ resulted in a decrease in the $\mathrm{NO}$ adsorption capacity from 81.67 to $21.83 \mathrm{mg} / \mathrm{g}$ for pristine, 142.53 to $42.54 \mathrm{mg} / \mathrm{g}$ for Ce-loaded and 470.59 to 217.94 $\mathrm{mg} / \mathrm{g}$ for $\mathrm{KOH}$-activated biochar. When the adsorption temperature increased from 30 to 110 oC, the adsorption capacity decreased from 81.67 to $34.07 \mathrm{mg} / \mathrm{g}$ for pristine, 142.53 to 95.42 $\mathrm{mg} / \mathrm{g}$ for Ce-loaded 470.59 to $298.15 \mathrm{mg} / \mathrm{g}$ for $\mathrm{KOH}$-activated biochar. This was associated 
with the exothermic nature of the adsorption process. In terms of stability, all prepared adsorbents revealed good regeneration performance. Only 10 and 20\% decrease were detected in the NO uptake capacity of Ce-loaded and $\mathrm{KOH}$-activated biochars, respectively, after 5 regeneration cycles.

\section{Funding}

This research was supported by the Long-Term Research Grant Scheme 203/PJKIMIA/6720009 from the Ministry of Education, Malaysia.

\section{Acknowledgments}

The authors are grateful to the School of Chemical Engineering, Universiti Sains Malaysia, for providing support and research facilities to accomplish this study.

\section{Conflicts of Interest}

The authors declare no conflict of interest.

\section{References}

1. Sumathi S.; Bhatia S.; Lee K.; Mohamed A. Cerium impregnated palm shell activated carbon (Ce/PSAC) sorbent for simultaneous removal of $\mathrm{SO}_{2}$ and $\mathrm{NO}$-Process study. Chem. Eng. J. 2010, 162, 51-57, https://doi.org/10.1016/J.CEJ.2010.04.056.

2. Zhang J.; Ghirardo A.; Gori A.; Albert A.; Buegger F.; Pace R.; Georgii E.; Grote R.; Schnitzler J.-P.; Durner J. Improving air quality by nitric oxide consumption of climate-resilient trees suitable for urban greening. Front. Plant Sci. 2020, 11, https://dx.doi.org/10.3389\%2Ffpls.2020.549913.

3. Yang J.; Zhou J.; Tong W.; Zhang T.; Kong M.; Ren S. Low-temperature flue gas denitration with transition metal oxides supported on biomass char. J. Energy Inst. 2019, 92, 1158-1166, https://doi.org/10.1016/j.joei.2018.06.002.

4. Zhang X.; Lin R. Effect of Alkali Metal Elements on Nitric Oxide Chemisorption at the edge of Char: A DFT study. Energy Procedia 2019, 158, 4805-4809, https://doi.org/10.1016/j.egypro.2019.01.716.

5. Li X.; Gao H. DFT analysis of NO adsorption on the undoped and Ce-doped $\mathrm{LaCoO}_{3}(011)$ surface. Materials 2019, 12, 1379, https://doi.org/10.3390/ma12091379.

6. Chen H.; Wang Y.; Lyu Y.-K. High catalytic activity of Mn-based catalyst in NO oxidation at low temperature and over a wide temperature span. Mol. Catal. 2018, 454, 21-29, https://doi.org/10.1016/j.mcat.2018.05.001.

7. Abujarada S.; Walton A.S.; Thomas A.G.; Chohan U.K.; Koehler S.P. Adsorption site, orientation and alignment of NO adsorbed on Au (100) using 3D-velocity map imaging, X-ray photoelectron spectroscopy and density functional theory. Phys. Chem. Chem. Phys. 2019, 21, 10939-10946, https://doi.org/10.1039/C9CP01963D.

8. Han L.; Cai S.; Gao M.; Hasegawa J.-y.; Wang P.; Zhang J.; Shi L.; Zhang D. Selective catalytic reduction of NOx with $\mathrm{NH}_{3}$ by using novel catalysts: state of the art and future prospects. Chem. Rev. 2019, 119, 1091610976, https://doi.org/10.1021/acs.chemrev.9b00202.

9. Gao F.; Chu C.; Zhu W.; Tang X.; Yi H.; Zhang R. High-efficiency catalytic oxidation of nitric oxide over spherical MnCo spinel catalyst at low temperature. Appl. Surf. Sci. 2019, 479, 548-556, https://doi.org/10.1016/j.apsusc.2019.02.116.

10. Adapa S.; Gaur V.; Verma N. Catalytic oxidation of NO by activated carbon fiber (ACF). Chem. Eng. J. 2006, 116, 25-37, https://doi.org/10.1016/j.cej.2005.10.007.

11. Al-Rahbi A.S.; Williams P.T. Production of activated carbons from waste tyres for low temperature NOx control. Waste Manage. 2016, 49, 188-195, https://doi.org/10.1016/j.wasman.2016.01.030.

12. Deng W.; Tao C.; Cobb K.; Zhou H.; Su Y.; Ruan R. Catalytic oxidation of NO at ambient temperature over the chars from pyrolysis of sewage sludge. Chemosphere 2020, 251, 126429, https://doi.org/10.1016/j.chemosphere.2020.126429. 
13. You F.-T.; Yu G.-W.; Xing Z.-J.; Li J.; Xie S.-Y.; Li C.-X.; Wang G.; Ren H.-Y.; Wang Y. Enhancement of NO catalytic oxidation on activated carbon at room temperature by nitric acid hydrothermal treatment. Appl. Surf. Sci. 2019, 471, 633-644, https://doi.org/10.1016/j.apsusc.2018.12.066.

14. You F.-T.; Yu G.-W.; Wang Y.; Xing Z.-J.; Liu X.-J.; Li J. Study of nitric oxide catalytic oxidation on manganese oxides-loaded activated carbon at low temperature. Appl Surf Sci 2017, 413, 387-397, https://doi.org/10.1016/j.apsusc.2017.04.044.

15. Xiao X.; Chen B.; Chen Z.; Zhu L.; Schnoor J.L. Insight into multiple and multilevel structures of biochars and their potential environmental applications: a critical review. Environ. Sci. Technol. 2018, 52, 5027-5047, https://doi.org/10.1021/acs.est.7b06487.

16. Do Minh T.; Song J.; Deb A.; Cha L.; Srivastava V.; Sillanpää M. Biochar based catalysts for the abatement of emerging pollutants: a review. Chem. Eng. J. 2020, 394, 124856, https://doi.org/10.1016/j.cej.2020.124856.

17. Kong M.; Liu Q.; Guo F.; Jiang L.; Yao L.; Ren S.; Yang J. Physicochemical properties of pine-derived biochars modified by metal oxides and their performance in the removal of NO. J. Energy Inst. 2018, 91, 467472, https://doi.org/10.1016/j.joei.2017.01.006.

18. Anthonysamy S.I.; Lahijani P.; Mohammadi M.; Mohamed A.R. Low temperature adsorption of nitric oxide on cerium impregnated biomass-derived biochar. Korean J. Chem. Eng. 2020, 37, 130-140, https://doi.org/10.1007/s11814-019-0405-9.

19. Hassan M.; Liu Y.; Naidu R.; Parikh S.J.; Du J.; Qi F.; Willett I.R. Influences of feedstock sources and pyrolysis temperature on the properties of biochar and functionality as adsorbents: A meta-analysis. Sci. Total Environ. 2020, 140714, https://doi.org/10.1016/j.scitotenv.2020.140714.

20. Ghafari M.; Atkinson J.D. Catalytic NO oxidation in the presence of moisture using porous polymers and activated carbon. Environ. Sci. Technol. 2016, 50, 5189-5196, https://doi.org/10.1021/acs.est.5b05443.

21. Fakayode O.A.; Aboagarib E.A.A.; Zhou C.; Ma H.; Co-pyrolysis of lignocellulosic and macroalgae biomasses for the production of biochar-A review. Bioresour. Technol. 2020, 297, 122408, https://doi.org/10.1016/j.biortech.2019.122408.

22. Lahijani P.; Mohammadi M.; Mohamed A.R. Catalytic $\mathrm{CO}_{2}$ gasification of rubber seed shell-derived hydrochar: reactivity and kinetic studies. Environ. Sci. Pollut. Res. 2019, 26, 11767-11780, https://doi.org/10.1007/s11356-019-04613-4.

23. Zhao Y.; Wang H.; Wang T. Adsorption of NO from flue gas by molecularly imprinted adsorbents. Chem. Eng. J. 2016, 306, 832-839, https://doi.org/10.1016/j.cej.2016.08.023.

24. Stoyanova D.; Georgieva P.; Avramova I.; Aleksieva K.; Marinova D.; Mehandjiev D. Nitric oxide (NO) decomposition on catalysts, containing oxides of lanthanum and cerium, supported on $\gamma$-alumina. J. Rare Earths 2019, 37, 151-159, https://doi.org/10.1016/j.jre.2018.06.009.

25. Ding S.; Liu Y. Adsorption of $\mathrm{CO}_{2}$ from flue gas by novel seaweed-based $\mathrm{KOH}$-activated porous biochars. Fuel 2020, 260, 116382, https://doi.org/10.1016/j.fuel.2019.116382.

26. Li P.; Ge B.; Zhang S.; Chen S.; Zhang Q.; Zhao Y. $\mathrm{CO}_{2}$ capture by polyethylenimine-modified fibrous adsorbent. Langmuir 2008, 24, 6567-6574, https://doi.org/10.1021/la800791s.

27. Wang J.; Krishna R.; Yang J.; Dandamudi K.P.R.; Deng S. Nitrogen-doped porous carbons for highly selective $\mathrm{CO}_{2}$ capture from flue gases and natural gas upgrading. Mater. Today Commun. 2015, 4, 156-165, https://doi.org/10.1016/j.mtcomm.2015.06.009.

28. Hosseini S.; Marahel E.; Bayesti I.; Abbasi A.; Abdullah L.C.; Choong T.S. $\mathrm{CO}_{2}$ adsorption on modified carbon coated monolith: effect of surface modification by using alkaline solutions. Appl. Surf. Sci. 2015, 324, 569-575, https://doi.org/10.1016/j.apsusc.2014.10.054.

29. Goel C.; Bhunia H.; Bajpai P.K. Novel nitrogen enriched porous carbon adsorbents for $\mathrm{CO}_{2}$ capture: Breakthrough adsorption study. J. Environ. Chem. Eng. 2016, 4, 346-356, https://doi.org/10.1016/j.jece.2015.11.017.

30. Monazam E.R.; Spenik J.; Shadle L.J. Fluid bed adsorption of carbon dioxide on immobilized polyethylenimine (PEI): Kinetic analysis and breakthrough behavior. Chem. Eng. J. 2013, 223, 795-805, https://doi.org/10.1016/j.cej.2013.02.3041.

31. Zhu Z.; Liu Z.; Liu S.; Niu H. Adsorption and reduction of NO over activated coke at low temperature. Fuel 2000, 79, 651-658, https://doi.org/10.1016/S0016-2361(99)00192-1.

32. Munusamy K.; Sethia G.; Patil D.V.; Rallapalli P.B.S.; Somani R.S.; Bajaj H.C. Sorption of carbon dioxide, methane, nitrogen and carbon monoxide on MIL-101 (Cr): volumetric measurements and dynamic adsorption studies. Chem. Eng. J. 2012, 195, 359-368, https://doi.org/10.1016/j.cej.2012.04.071. 
33. Zulkefli N.N.; Masdar M.S.; Isahak W.; Jahim J.; Majlan E.; Rejab S.; Lye C. Mathematical modelling and simulation on the adsorption of Hydrogen Sulfide $\left(\mathrm{H}_{2} \mathrm{~S}\right)$ gas. IOP Conference Series: Materials Science and Engineering: IOP Publishing; 2017, 012069, https://doi.org/10.1088/1757-899X/206/1/012069.

34. Wang J.; Huang H.; Wang M.; Yao L.; Qiao W.; Long D.; Ling L. Direct capture of low-concentration $\mathrm{CO}_{2}$ on mesoporous carbon-supported solid amine adsorbents at ambient temperature. Ind. Eng. Chem. Res. 2015, 54, 5319-5327, https://doi.org/10.1021/acs.iecr.5b01060.

35. Tan Y.; Islam M.A.; Asif M.; Hameed B. Adsorption of carbon dioxide by sodium hydroxide-modified granular coconut shell activated carbon in a fixed bed. Energy 2014, 77, 926-931, https://doi.org/10.1016/j.energy.2014.09.079.

36. Al-Rahbi A.S.; Nahil M.A.; Wu C.; Williams P.T. Waste-derived activated carbons for control of nitrogen oxides. Proceedings of the Institution of Civil Engineers-Waste and Resource Management: Thomas Telford Ltd; 2016. 30-41.

37. Tiwari D.; Bhunia H.; Bajpai P.K. Synthesis of nitrogen enriched porous carbons from urea formaldehyde resin and their carbon dioxide adsorption capacity. J. CO2 Util. 2017, 21, 302-313, https://doi.org/10.1016/j.jcou.2017.08.002.

38. Goel C.; Bhunia H.; Bajpai P.K. Resorcinol-formaldehyde based nanostructured carbons for $\mathrm{CO}_{2}$ adsorption: Kinetics, isotherm and thermodynamic studies. RSC Adv. 2015, 5, 93563-93578, https://doi.org/10.1039/C5RA16255F.

39. Ammendola P.; Raganati F.; Chirone R.; Miccio F. Fixed bed adsorption as affected by thermodynamics and kinetics: Yellow tuff for $\mathrm{CO}_{2}$ capture. Powder Technol. 2020, 373, 446-458, https://doi.org/10.1016/j.powtec.2020.06.075.

40. Balsamo M.; Budinova T.; Erto A.; Lancia A.; Petrova B.; Petrov N.; Tsyntsarski B. $\mathrm{CO}_{2}$ adsorption onto synthetic activated carbon: Kinetic, thermodynamic and regeneration studies. Sep. Purif. Technol. 2013, 116, 214-221, https://doi.org/10.1016/j.seppur.2013.05.041.

41. Cao F.; Chen J.; Ni M.; Song H.; Xiao G.; Wu W.; Gao X.; Cen K. Adsorption of NO on ordered mesoporous carbon and its improvement by cerium. RSC Adv. 2014, 4, 16281-16289, https://doi.org/10.1039/C4RA01409J.

42. Guo Y.; Li Y.; Zhu T.; Ye M. Investigation of $\mathrm{SO}_{2}$ and $\mathrm{NO}$ adsorption species on activated carbon and the mechanism of $\mathrm{NO}$ promotion effect on $\mathrm{SO}_{2}$. Fuel 2015, 143, 536-542, https://doi.org/10.1016/j.fuel.2014.11.084.

43. Sumathi S.; Bhatia S.; Lee K.; Mohamed A. Selection of best impregnated palm shell activated carbon (PSAC) for simultaneous removal of $\mathrm{SO}_{2}$ and NOx. J. Hazard. Mater. 2010, 176, 1093-1096, https://doi.org/10.1016/j.jhazmat.2009.11.037. 